\title{
A comparative study on morphology, growth rate and reproduction of Clarias gariepinus (Burchell, 1822), Heterobranchus longifilis Valenciennes, 1840, and their reciprocal hybrids (Pisces, Clariidae)
}

\author{
M. Legendre* $\uparrow$, G. G. Teugels $\ddagger$, C. Cauty $\$$ and B. Jalabert\$ \\ ${ }^{*}$ Centre de Recherches Océanographiques, BP VI8, Abidjan, Ivory Coast, $¥$ Laboratoire \\ d'Ichtyologie, Musée Royal de l'Afrique Centrale, B-3080, Tervuren, Belgium and \\ $\$$ Laboratorie de Physiologie des Poissons, INRA, Campus de Beaulieu, F-35042 Rennes
} Cedex, France

(Received 12 April 1991, Accepted 2 July 1991)

\begin{abstract}
Successful reciprocal hybridizations between Clarias gariepinus and Heterobranchus longifilis were performed during three experiments. The reciprocal hybrids were viable, their survival rates being similar to those found in the maternal species. Hybrid morphology was intermediate to that of the parents. No difference in external morphology was found between the reciprocal hybrids. Growth rate comparison under the same conditions and over a period of 307 days, revealed a considerably faster growth for $H$. longifilis than for $C$.gariepinus, and demonstrated the importance of the use of the former species in fish culture. Hybrid growth rates were similar to that of $H$. longiflis, although during one of the experiments female $H$. longifilis $\times$ male $C$. gariepinus hybrids displayed an even faster growth than $H$. longifilis.

A detailed study on reproduction indicated that female $C$. gariepinus mature earlier (5-7 months) than female $H$. longifilis (12-14 months). In the reciprocal hybrids, female first sexual maturity was attained at 20-21 months. Both reciprocal hybrids and parental species displayed an equilibrated sex ratio. Macroscopical and microscopical observations revealed numerous abnormalities in gonadal development of the hybrids. GSI and fecundity in female hybrids were considerably lower than those found in the parental species. Moreover, intra-ovarian tumors occurred in $20 \%$ of the hybrids. In hybrid males, GSIs were generally higher than those found in the parental species, but the spermatozoa concentration in the semen was about 100 times less. Despite these abnormalities, viable larvae, resulting from $F 2$ and backcross fertilizations, were obtained.
\end{abstract}

Key words: Africa; Clarias gariepinus; Heterobranchus longifilis; hybridization; morphology; growth; reproduction.

\section{INTRODUCTION}

Clariid catfishes occur both in south-east Asia and in Africa. The highest generic diversity is found on the African continent where some 14 genera have been reported (Teugels, 1986a) against two in south-east Asia. In both continents, Clariidae are of great economic importance as food fish. For several years, species of the genus Clarias Scopoli, 1777 have been used in local fish culture where they proved to be a fast growing protein source. In south-east Asia, especially Clarias batrachus (Linnaeus, 1758) and to a lesser extent C. macrocephalus Günther, 1864 have been used, while in Africa C. gariepinus (Burchell, 1822) (with its junior synonyms $C$. lazera Valenciennes, 1840 and C. mossambicus Peters, 1858 see Teugels, 1982, 1986b) has generally been propagated.

†Present address: Centre ORSTOM, BP 5045, F-34032 Montpellier Cedex 1, France. 
Another African clariid, Heterobranchus longifilis Valenciennes, 1840, was introduced to aquaculture in the Ivory Coast a few years ago. The results obtained so far are most promising: $H$. longifilis is a very hardy, omnivorous fish, whose potential growth rate is one of the fastest yet observed amongst African fish species tested in aquaculture. It also proved to be highly suitable for brackish water culture up to $10 \mathrm{~g}^{-1}$ salinity (Legendre, 1983, 1991).

As interspecific cross-breeding in fish may lead to hybrids with valuable characteristics for culture (sterility, monosex population, heterosis for disease resistance or growth rate ...), it was decided to evaluate the potential interest of an artificial hybridization between C. gariepinus and $H$. longifilis. In contrast with the abundant literature on hybridizations in other cultured fish families, in particular cichlids, salmonids, cyprinids and ictalurids (for review see Sneed, 1971; Moav, 1976; Wohlfarth \& Hulata, 1981; Chevassus, 1979, 1983), reports on hybridization of clariid species are rather scarce.

Previous investigations on hybridization among Asiatic clariids involved $C$. macrocephalus and C. batrachus (Boonbrahm et al., 1977), C. batrachus or C. macrocephalus $\times$ Pangasius sutshi (Tarnchalanukit, 1986) and C. batrachus $\times$ Heteropneustes fossilis (Mukhopadathy \& Dehadrai, 1987). The only paper on hybridization among African clariids involves the same two species as in our investigation, $C$. gariepinus females were crossed with a male of $H$. longifilis (Hecht $\&$ Lublinkhof, 1985). However, except for a general description of larval morphology and a short-term comparison of growth rates between the hybrid and the female parent, no information is given on other hybrid characters. The question of possible sterility of the hybrid remained unanswered.

In the present paper, reciprocal hybridization between $C$. gariepinus and $H$. longifilis is reported. The morphology of the F1 hybrids is described and their viability and growth rates are compared to those of both parental species over a 10 month period. Sex ratio, as well as weight and age at first sexual maturity, are given for parents and hybrids. Finally, the fertility of the hybrids is examined in terms of gametogenesis efficiency and gamete viability.

A karyological analysis and a study of enzymatic polymorphism of the hybrids are presented in two other papers (Teugels et al., 1992a,b).

\section{MATERIALS AND METHODS}

Three hybridization experiments were performed in March 1987, April 1988 and May 1989 at the Layo aquaculture research station, located $40 \mathrm{~km}$ west of Abidjan on the edge of the Ebrié lagoon (Ivory Coast).

In this area, four climatic seasons are distinguished: a major dry season from December to April, a major rainy season from May to July, a minor dry season from August to September and a minor rainy season from October to November. The water characteristics at the station are strongly influenced by the vicinity of the Agneby River estuary in the Ebrie lagoon and the season. Water salinity is lowest $\left(0\right.$ to $\left.4 \mathrm{~g} \mathrm{l}^{-1}\right)$ from June to December, while its maximum ( 6 to $10 \mathrm{~g}^{-1}$ ) occurs between January and May. The water temperature fluctuates yearly between 25 and $32^{\circ} \mathrm{C}$ with a minimum corresponding to the major rainy season. Water $\mathrm{pH}$ generally ranges between 6.5 and 7.5 .

$H$. longifilis brooders used in these experiments came from a second generation of domesticated fish spawned at Layo, that descended originally from wild stocks that spontaneously colonized the fish ponds of the station in 1982 (Legendre, 1983). C. gariepinus brooders were obtained from the experimental fish culture station of the Institut des 
Savannes (IDESSA) at Bouaké, Ivory Coast. Specimens of brooders from both species, as well as several specimens of their reciprocal hybrids were deposited in the Musée Royal de l'Afrique Centrale (MRAC) Tervuren and in the Muséum National d'Histoire Naturelle (MNHN) Paris. Clarias specimens were identified following Teugels (1986b), while Heterobranchus specimens were named after Teugels et al. (1990).

Oocyte maturation and ovulation were induced following treatments established previously for each species. In $H$. longifilis, a single injection of human chorionic gonadotropin (HCG) at a dose of 1.5 IU per g B.W. was used (Legendre, 1986). C. gariepinus females were injected either with carp pituitary suspension $(4 \mu \mathrm{g}$ per g B.w.; see Hogendoorn \& Vismans, 1980) or with HCG (4.0 IU per g B.w.; see Eding et al., 1983). Depending on water temperature and hormone used, latency time between injection and stripping of females followed the recommendations made by these authors. Methods of choice of brooders, sperm collection, artificial fertilization and egg incubation were described previously (Legendre, 1986).

In each experiment, hybrids and control groups were produced on the same day and from the same parents by fertilizing pooled eggs from three females using pooled semen from three males. The success of each cross, intra- or interspecific, was evaluated by the percentages of normal larvae obtained after hatching from control aliquots of 200-300 eggs (two replications per cross).

One or two days after hatching, batches of normal larvae were sorted, counted and transferred into the rearing facilities. Growth rates and survivals of the four groups (both parental species and reciprocal hybrids) were compared in separate tests.

In 1987, batches of 3500 larvae (four replications per group) were placed in $4 \mathrm{~m}^{2}$ outdoor concrete tanks $(0.5 \mathrm{~m}$ depth) supplied with lagoon water. The fry were fed daily with live zooplankton collected from ponds and received a supplementary ration of a trout starter (Trouvit 000) distributed ad libitum four times per day. After 15 days the tanks were emptied, the surviving fry counted and samples of 30 fish per tank weighed individually to the nearest $0 \cdot 1 \mathrm{mg}$. The fry were then returned to their tank for 6 weeks during which they were fed with a $45 \%$ crude protein pelleted feed distributed twice per day at a daily rate of $10 \%$ of fish biomass. Samples of 30 to 50 fish per tank were weighed weekly $(W \pm 0.01 \mathrm{~g})$ to establish growth curves and readjust the feeding ration.

The growth comparison was ended after 57 days. Two populations of approximately 250 specimens of $H$. longifilis and $H \times C$ hybrid* were isolated for the reproduction study (no survivors remained in the two other groups, see results). They were reared separately in concrete tanks up to 28 months of age and received a $35 \%$ protein pelleted feed distributed twice a day at a daily rate of $3 \%$ of fish biomass. Periodically, three to five males and seven to 10 females of each group were killed for examination of gonad development.

In 1988, larvae were reared in troughs supplied with lagoon water and fed with Artemia salina nauplii. This was unsuccessful due to problems of water quality. Only a few tens of fish of each group, very mixed in size, survived after 15 days. Therefore, no rigorous growth comparison could be made. The fish were reared for 15 months in the concrete tanks and then killed for gonad examination at the same time as fish from the 1987 experiment.

In 1989, batches of 800 larvae (two replications per group) were placed separately in 601 tanks of a tapwater recirculating system. The fry were fed ad libitum six times per $24 \mathrm{~h}$ with Artemia salina nauplii. From day 9, artificial feeding (Trouvit 000 ) was introduced and progressively replaced Artemia nauplii. After 2 weeks, the surviving larvae were counted and their mean weight determined to the nearest $0.1 \mathrm{mg}$ from samples of 30 individuals per tank. Then, the fish of each group were pooled, and tranferred to the $4 \mathrm{~m}^{2}$ outdoor tanks for a transitory growth period. They were fed six times per day with trout pellets at a daily rate of $20 \%$ of fish biomass.

On day 53, all the fish were counted again and samples of 40 fish per group were weighed individually $(\mathrm{W} \pm 0.1 \mathrm{~g})$. Then, trying to respect the original mean weight, each population was sorted by discarding smaller and bigger fish in order to constitute duplicate batches of 36 individuals of each group. This was done in order to avoid possible bias on survival and growth rates due to cannibalism. All the selected fish were weighed and returned to the

${ }^{*}$ Hybrid crosses are given throughout with the female parent in the first position and species names abbreviated by the first letter of their generic name. 
concrete tanks for initiation of the grow-out trial. They were then fed with a locally made $45 \%$ protein pelleted feed distributed four times per day at a daily rate of $5 \%$ of fish biomass. The daily ration was reduced to $4 \%$ after 126 days of grow-out.

Every 14 days, all the fish from each tank were weighed individually $(\mathrm{W} \pm 1 \mathrm{~g})$ and the feeding ration readjusted. After 254 days of grow-out, they were killed for sex ratio determination and examination of gonad development. The feed conversion ratios were calculated for the entire grow-out period by the following relation: total weight of distributed feed/total gain in fish biomass.

During the three experiments, body weight of each individual was determined to the nearest $1 \mathrm{~g}$. The gonads were checked macroscopically for maturity stage and then weighed to the nearest $0.01 \mathrm{~g}$ for gonado-somatic index (GSI) calculation (gonad weight/total body weight $\times 100$ ). In females, individuals with ovaries containing oocytes in advanced vitellogenesis were considered as maturing and those with ovaries containing post-vitellogenic oocytes (diameter $>1 \mathrm{~mm}$ ) were considered as mature. In males, the presence of intratesticular sperm was the criterion of full maturity.

The weight and age at first sexual maturity were defined as the weight or age at which $50 \%$ of the fish reached an advanced maturity stage. In the first experiment, this was determined directly from observations made on fish killed periodically. In the second and third experiments, first maturity was determined in females by periodically checking oocyte development in samples obtained by in vivo intra-ovarian biopsy with a plastic catheter.

Fecundity was determined from preserved ovaries sampled from mature females. It was defined as the number of oocytes belonging to the largest diameter modal group. The spermatozoa concentration was determined using a Thomas's hematimeter after dilution (dilution rate of $2 \cdot 10^{-3}$ to $2 \cdot 10^{-2}$ ) of intratesticular semen in an $0.9 \% \mathrm{NaCl}$ solution. For histological examination, central parts of gonads were fixed in Bouin fluid, dehydrated and embedded in paraffin. Sections of 5 to $10 \mu \mathrm{m}$ were stained with Regaud hematoxylin, orange $\mathrm{G}$, and anilin blue (Gabe, 1968).

After induction of ovulation in three hybrid females with a single HCG injection at a dose of $2.5 \mathrm{IU}$ per $\mathrm{g}$ B.W., the viability of hybrid gametes was evaluated through hatching rates of hybrid eggs fertilized either with hybrid sperm (F2) or with sperm of parents (backcross). Simultaneously, the fertilizing ability of hybrid spermatozoa was tested in reciprocal backcrosses with $H$. longifilis and $C$. gariepinus eggs. Intraspecific fertilizations served as controls. A pool of gametes from three males and three females was always used, except in the case of hybrid females for which eggs were tested separately.

\section{STATISTICAL ANALYSES}

Paired data were analysed by Student's $t$-test and multiple means were treated by one-way or two-way (replicates $\times$ treatments) analyses of variance followed by Duncan's multiple-range test. When necessary, analyses were performed after logarithmic transformation for weights or angular transformation for survival rates in order to stabilize residual variance. In text and tables, means are given with the confidence interval at $5 \%$ probability.

\section{RESULTS}

\section{INCUBATION TIME AND HATCHING RATES}

Hatching took place at approximately the same time for $C$. gariepinus, $H$. longifilis and their reciprocal hybrids, and was completed after 24 to $25 \mathrm{~h}$ postfertilization at a temperature of $27-29^{\circ} \mathrm{C}$. Hatching rates and proportions of deformed larvae in the three experiments (Fig. 1) showed that cross-fertilization between $C$. gariepinus and $H$. longifilis led to normal embryonic development. Proportions of deformed larvae in the hybrids were similar to those found in their maternal parent. Differences in hatching rates were greater between both parental species than between pure species and hybrids obtained from the same eggs. This shows that hatching rates were determined mostly by egg quality. 


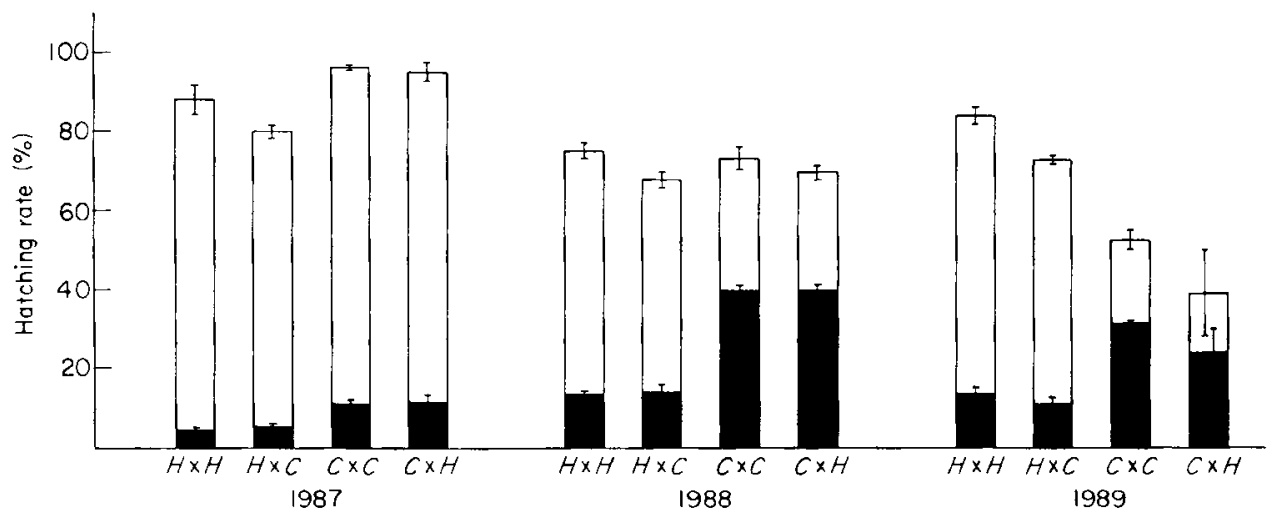

Fig. 1. Mean hatching rates (normal, $\square+$ deformed, $\square$ larvae) of $H$. longifilis $(H \times H), C$.gariepinus $(C \times C)$ and their reciprocal hybrids in the 1987,1988 and 1989 experiments. Vertical bars indicate range of replicates.

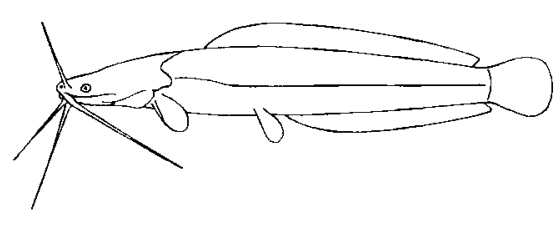

(a)

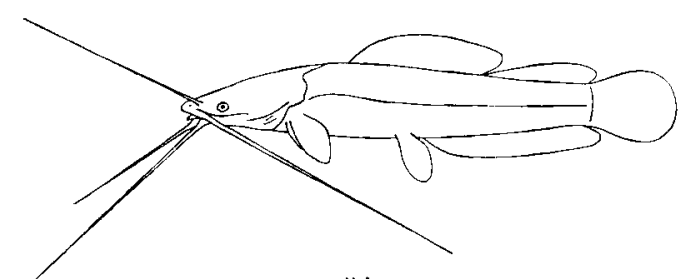

(b)

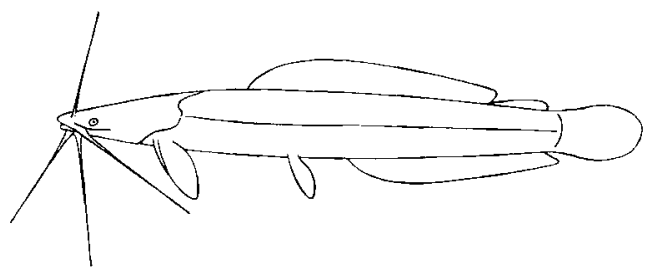

(c)

FIG. 2. Schematic outline of (a) Clarias gariepinus, (b) Heterobranchus longifilis and (c) their hybrid,

Contrary to the results of Hecht \& Lublinkhof (1985), no differences were found in the size of newly hatched larvae either from pure species or from hybrids, the mean total length of the different larval groups ranging between $4.5 \pm 0.1 \mathrm{~mm}$ and $4.6 \pm 0.1 \mathrm{~mm}$ on the day of hatching and between $7 \cdot 1 \pm 0.1 \mathrm{~mm}$ and $7.3 \pm 0.2 \mathrm{~mm}$ after 2 days.

\section{MORPHOLOGY AND COLORATION}

External morphological descriptions for $C$. gariepinus and $H$. longifilis are given in Teugels (1986b) and Teugels et al. (1990) respectively. We refer to these papers for details. A schematic illustration of both species and their hybrids is given in Fig. 2. 
TABLE I. Measurements and meristic counts for specimens of reciprocal hybrids of Clarias gariepinus and Heterobranchus longifilis

\begin{tabular}{|c|c|c|c|c|c|c|c|c|}
\hline & \multicolumn{4}{|c|}{$H \times C$} & \multicolumn{4}{|c|}{$\mathrm{C} \times \mathrm{H}$} \\
\hline & $n$ & $\min$ & $\max$ & $m$ & $n$ & $\min$ & $\max$ & $m$ \\
\hline Total length (T.L.) (mm) & 17 & 75 & 560 & - & 5 & 108 & 208 & - \\
\hline Standard length (S.L.) (mm) & 17 & 64 & 485 & - & 5 & 91 & 177 & - \\
\hline Body depth at anus (\% S.L.) & 6 & $12 \cdot 8$ & $17 \cdot 9$ & $14 \cdot 1$ & 5 & $13 \cdot 6$ & $14 \cdot 7$ & $14 \cdot 0$ \\
\hline Caudal peduncle depth (\% S.L.) & 6 & $7 \cdot 9$ & $10 \cdot 4$ & $9 \cdot 1$ & 5 & $8 \cdot 8$ & $9 \cdot 8$ & $9 \cdot 3$ \\
\hline Head length (HL) (\% S.L.) & 17 & $27 \cdot 3$ & $34 \cdot 0$ & $29 \cdot 6$ & 5 & $27 \cdot 3$ & $32 \cdot 5$ & $30 \cdot 8$ \\
\hline Head width ( $\%$ S.L.) & 7 & $18 \cdot 9$ & $24 \cdot 2$ & $20 \cdot 8$ & 5 & $19 \cdot 0$ & $22 \cdot 0$ & $20 \cdot 4$ \\
\hline Snout length (\% H.L.) & 7 & $21 \cdot 9$ & $27 \cdot 2$ & $23 \cdot 5$ & 5 & $24 \cdot 0$ & $25 \cdot 3$ & $24 \cdot 4$ \\
\hline Interorbital distance ( $\%$ H.L.) & 7 & $37 \cdot 1$ & $44 \cdot 9$ & $42 \cdot 1$ & 5 & $39 \cdot 7$ & $41 \cdot 3$ & $40 \cdot 5$ \\
\hline Nasal barbel length (\% H.L.) & 7 & $25 \cdot 5$ & $63 \cdot 8$ & - & 5 & $54 \cdot 4$ & 61.9 & - \\
\hline Maxillary barbel length (\% H.L.) & 6 & $102 \cdot 6$ & $118 \cdot 1$ & - & 5 & $94 \cdot 4$ & $125 \cdot 3$ & - \\
\hline $\begin{array}{l}\text { Internal mandibulary barbel L } \\
(\% \text { H.L. })\end{array}$ & 6 & $46 \cdot 2$ & $63 \cdot 4$ & - & 5 & $54 \cdot 4$ & $62 \cdot 1$ & - \\
\hline $\begin{array}{l}\text { External mandibulary barbel L } \\
(\% \text { H.L. })\end{array}$ & 6 & $67 \cdot 7$ & $92 \cdot 9$ & - & 5 & $83 \cdot 6$ & $97 \cdot 1$ & - \\
\hline Premaxillary width (\% H.L.) & 7 & $28 \cdot 6$ & $31 \cdot 9$ & $30 \cdot 0$ & 5 & $27 \cdot 3$ & $30 \cdot 5$ & $29 \cdot 5$ \\
\hline Vomerine width (\% H.L.) & 5 & $22 \cdot 7$ & $27 \cdot 7$ & $25 \cdot 2$ & 5 & $24 \cdot 3$ & $25 \cdot 5$ & $24 \cdot 9$ \\
\hline Predorsal distance (\% S.L.) & 7 & $31 \cdot 8$ & $37 \cdot 9$ & $35 \cdot 3$ & 5 & $32 \cdot 5$ & $37 \cdot 6$ & $35 \cdot 7$ \\
\hline Preanal distance (\% S.L.) & 7 & $55 \cdot 9$ & $62 \cdot 0$ & $57 \cdot 9$ & 5 & $55 \cdot 5$ & $59 \cdot 5$ & $58 \cdot 1$ \\
\hline Prepelv. distance (\% S.L.) & 7 & $47 \cdot 2$ & $53 \cdot 0$ & $49 \cdot 5$ & 5 & $45 \cdot 5$ & $51 \cdot 5$ & $48 \cdot 6$ \\
\hline Prepect. distance (\% S.L.) & 7 & $21 \cdot 6$ & $26 \cdot 5$ & $24 \cdot 3$ & 5 & $24 \cdot 7$ & $29 \cdot 5$ & $27 \cdot 2$ \\
\hline Dorsal fin length (\% S.L.) & 10 & $44 \cdot 3$ & $50 \cdot 7$ & $48 \cdot 7$ & 5 & $44 \cdot 6$ & $49 \cdot 0$ & $46 \cdot 6$ \\
\hline Adipose fin length (\% S.L.) & 15 & $14 \cdot 1$ & $19 \cdot 4$ & $17 \cdot 3$ & 5 & $13 \cdot 6$ & $16 \cdot 8$ & $15 \cdot 7$ \\
\hline Pectoral spine length (\% S.L.) & 5 & $7 \cdot 3$ & $10 \cdot 9$ & $8 \cdot 9$ & 5 & $7 \cdot 6$ & 9.9 & $8 \cdot 9$ \\
\hline Pectoral fin length (\% S.L.) & 7 & $13 \cdot 0$ & $14 \cdot 7$ & $13 \cdot 7$ & 5 & $13 \cdot 8$ & $15 \cdot 4$ & $14 \cdot 5$ \\
\hline Pelvic fin length (\% S.L.) & 7 & $10 \cdot 6$ & $12 \cdot 4$ & $11 \cdot 4$ & 5 & $9 \cdot 7$ & $13 \cdot 6$ & $11 \cdot 3$ \\
\hline Anal fin length (\% S.L.) & 7 & $37 \cdot 9$ & $44 \cdot 5$ & $41 \cdot 6$ & 5 & $38 \cdot 8$ & $42 \cdot 6$ & $41 \cdot 1$ \\
\hline Dorsal fin rays & 5 & 46 & 54 & - & 5 & 43 & 48 & - \\
\hline Vertebrae & 5 & 58 & 62 & - & 3 & 56 & 59 & - \\
\hline Extended neural spines & 4 & 15 & 17 & - & 4 & 15 & 16 & - \\
\hline Gill rakers on first arch & 10 & 19 & 40 & $\cdots$ & 5 & 27 & 35 & - \\
\hline
\end{tabular}

H. longifilis differs from C. gariepinus mainly by the presence of a large adipose fin (24.3-32.8\% S.L.) (absent in C. gariepinus), supported by 21 to 27 extended neural spines; a shorter dorsal fin ( $26 \cdot 9-34 \cdot 1 \%$ S.L. v. $56 \cdot 6 \cdot 67 \cdot 4 \%$ S.L.); fewer dorsal fin rays (26-35 v. 61-79) and fewer gill rakers on the first branchial arch (16-29v. 24-110).

The hybrids between the two species displayed an intermediate condition for the characters listed above: a small adipose fin (13.6-19.4\% S.L.) is present and supported by 15 to 17 extended neural spines; the dorsal fin length ranges between 44.3 and $50.7 \%$ S.L. with 43 to 54 rays; the number of gill rakers ranged between 19 and 40, increasing with the standard length. The most important morphometric and meristic characters for the reciprocal hybrids are listed in Table I. Except for differences in barbel lengths and gill raker number related to the different sizes of both samples and to allometric variation, both hybrid groups show a nearly identical external morphology. 


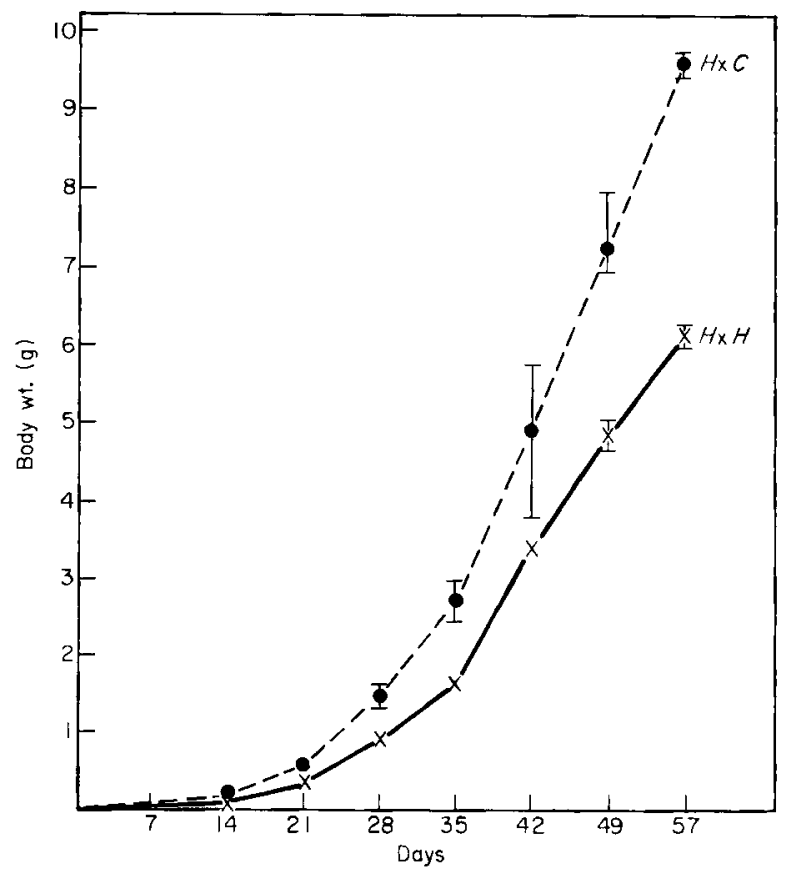

Fig. 3. Growth of $H$. longifilis $(H \times H)$ and $H \times C$ hybrids $(H \times C)$ in the 1987 experiment. Vertical bars indicate range of replicates.

All Clarias specimens had a marked marbled coloration. About $80 \%$ of the Heterobranchus specimens offered a uniform greyish colour, while the remaining $20 \%$ showed a slightly marbled colour. For $H \times C$ hybrids, $57 \%$ were slightly marbled, $39 \%$ had a markedly marbled colour pattern and $4 \%$ were uniform greyish. For $C \times H$ hybrids, however, about $30 \%$ were slightly marbled while some $70 \%$ were strongly marbled. Not a single $C \times H$ hybrid had a uniform coloration. The reciprocal hybrids therefore displayed a colour pattern, intermediate to that of the parental species, but with an apparent maternal influence. It should be noted that these colour observations were made whilst the fishes were out of the water and evidently subject to stress conditions.

\section{SURVIVAL AND GROWTH RATES}

In April 1987, at the end of yolk sac resorption (day 2), the larvae of the four groups were placed in outdoor concrete tanks filled with lagoon water, but the salinity $\left(8 \mathrm{~g}^{-1}\right)$ exceeded their tolerance limits, as recently demonstrated for H. longifilis (Legendre, 1991). This caused total mortality, within 3 days, of both C. gariepinus and $C \times H$ hybrids larvae, while after 15 days, the survival rates of $H$. longifilis $(1 \cdot 8 \pm 0.9 \%)$ and $H \times C$ hybrids $(6 \cdot 0 \pm 2 \cdot 8 \%)$ were also very low but significantly higher for the hybrid $(P<0 \cdot 01)$. Nevertheless, the growth of remaining fishes was followed up to 57 days of age. The results (Fig. 3) indicated that $H \times C$ hybrids displayed a faster growth rate than $H$. longifilis. The difference in mean weight was already significant after 14 days $(201 \pm 28 \mathrm{mg}$ against $96 \pm 10 \mathrm{mg})$. At the end of the experiment, after 57 days, the mean weight was $9.6 \pm 0.9 \mathrm{~g}$ for the $H \times C$ hybrid and $6 \cdot 1 \pm 0 \cdot 8 \mathrm{~g}$ for $H$. longifilis. 
TABLE II. Mean body weight and survival rates for $H$. longifilis $(H \times H), C$.gariepinus $(C \times C)$ and their reciprocal hybrids after 15 and 53 days of age in the 1989 experiment

\begin{tabular}{|c|c|c|c|c|}
\hline \multirow{2}{*}{$\begin{array}{l}\text { Fish } \\
\text { group }\end{array}$} & \multicolumn{2}{|c|}{ Day $15 \dagger$} & \multicolumn{2}{|c|}{ Day $53 \ddagger$} \\
\hline & $\begin{array}{l}\text { Body wt. } \\
\text { (mg) }\end{array}$ & $\begin{array}{c}\text { Survival } \\
(\%)\end{array}$ & $\begin{array}{l}\text { Body wt. } \\
\text { (g) }\end{array}$ & $\begin{array}{c}\text { Survival } \\
(\%)\end{array}$ \\
\hline$H \times H$ & $76 \cdot 5 \pm 7 \cdot 4^{a}$ & $81 \cdot 6^{a}$ & $5 \cdot 9 \pm 0 \cdot 7^{a}$ & $67 \cdot 7^{\mathrm{a}}$ \\
\hline$H \times C$ & $86.7 \pm 8.9^{a}$ & $93 \cdot 6^{b}$ & $6.7 \pm 0.9^{a}$ & $65 \cdot 5^{\mathrm{a}}$ \\
\hline$C \times C$ & $76 \cdot 6 \pm 15 \cdot 7^{\mathrm{a}}$ & $16 \cdot 6^{\circ}$ & $4 \cdot 4 \pm 1 \cdot 2^{b}$ & $7 \cdot 1^{b}$ \\
\hline$C \times H$ & $84 \cdot 7 \pm 15 \cdot 9^{a}$ & $18 \cdot 2^{\circ}$ & $6 \cdot 7 \pm 1 \cdot 6^{a}$ & $6 \cdot 3^{b}$ \\
\hline
\end{tabular}

Figures with same superscripts in the same column are not significantly different $(P<0.05)$.

† Means of duplicates.

† Single observations.

These results were not confirmed in the 1989 experiment since after 15 days of larval rearing in recirculating tap water, no difference was found in the mean weight of larvae whatever the species or hybrid considered (Table II). At this stage, the survival rate was higher for $H$. longifilis and $H \times C$ hybrids (81.6 and $93.6 \%$, respectively) than for $C$. gariepinus and $C \times H$ hybrids (16.6 and $18.2 \%$, respectively). This could be related to the poor quality of the Clarias eggs obtained after hormonal treatment in this experiment (Fig. 1).

After 53 days, a maternal effect was still observed in fish survival rates (Table II). At that time, the mean weights already indicated a slower growth rate for $C$. gariepinus $(P<0.05)$, while no statistical difference could be shown between $H$. longifilis and both hybrids' growth rates (Table II).

Because of this initial growth difference, but also due to the size segregation performed on day 53 (slight changes in mean weights and reduction of population heterogeneity), the mean initial weights of the fish selected for the grow-out trial were not equivalent in all groups (Table III). Except for both hybrids, which remained of equivalent initial weights, growth rates during grow-out could therefore not be compared directly on a final weight basis. This comparison necessitated the use of specific growth rate $(S G R)[S G R=(\ln W 2-\ln W 1) \times 100 / t]$ or relative weight gain $(\mathrm{RWG})[\mathrm{RWG}=((\mathrm{W} 2-\mathrm{W} 1) / \mathrm{W} 1) \times 100 / \mathrm{t}]$ as the growth parameters.

The results obtained for growth, food conversion ratio (FCR) and survival rate after a 254 days grow-out period are given in Table III. The corresponding growth curves are illustrated in Fig. 4.

It is clear from the data that $C$. gariepinus displayed a drastically slower growth rate than $H$. longifilis and both hybrids. This was confirmed by a significantly lower mean SGR and RWG $(P<0 \cdot 05)$.

Although $H \times C$ hybrids showed the greatest absolute weight gain, no significant growth difference was found on a SGR basis in the group constituted by $H$. longifilis and both reciprocal hybrids. However, because they were of equivalent initial weights, a direct comparison of final weight was permitted between $H \times C$ and $C \times H$ hybrids. This demonstrated a faster growth rate of the $H \times C$ hybrid 
TABLE III. Initial body weight, final body weight, specific growth rate (SGR), relative weight gain (RWG), feed conversion ratio (FCR) and survival rate for $H$. longifilis $(H \times H)$, C. gariepinus $(C \times C)$ and their reciprocal hybrids in the 254 days grow-out trial of the 1989 experiment (means of duplicates) trial initiated with 53-day-old fish

\begin{tabular}{|c|c|c|c|c|c|c|}
\hline $\begin{array}{l}\text { Fish } \\
\text { group }\end{array}$ & $\begin{array}{l}\text { Initial wt. } \\
\text { (g) }\end{array}$ & $\begin{array}{l}\text { Final wt. } \\
(\mathrm{g})\end{array}$ & $\underset{\left(\% \text { day }^{-1}\right)}{\text { SGR }}$ & $\begin{array}{c}\text { RWG } \\
\left(\% \text { day }^{-1}\right)\end{array}$ & FCR & $\begin{array}{c}\text { Survival } \\
(\%)\end{array}$ \\
\hline$H \times H$ & $6 \cdot 3 \pm 0 \cdot 3^{a}$ & $694 \pm 45$ & $1 \cdot 85^{4}$ & $43 \cdot 0^{\mathrm{a}, \mathrm{b}}$ & 3.99 & $95 \cdot 8^{\mathrm{a}}$ \\
\hline$H \times C$ & $7 \cdot 3 \pm 0.4^{b}$ & $908 \pm 103$ & $1.90^{\mathrm{a}}$ & $48 \cdot 5^{\mathrm{a}}$ & 3.97 & $80 \cdot 0^{a, b}$ \\
\hline$C \times C$ & $5 \cdot 3 \pm 0 \cdot 6^{c}$ & $369 \pm 65$ & $1.67^{b}$ & $27 \cdot 4^{c}$ & 4.07 & $53 \cdot 1^{\mathrm{b}}$ \\
\hline$C \times H$ & $7 \cdot 4 \pm 0.7^{b}$ & $749 \pm 125$ & $1 \cdot 82^{\mathrm{a}}$ & $39 \cdot 7^{\mathrm{b}}$ & 3.91 & $61 \cdot 1^{\mathrm{b}}$ \\
\hline
\end{tabular}

Figures with same superscripts in the same column are not significantly different $(P<0 \cdot 05)$.

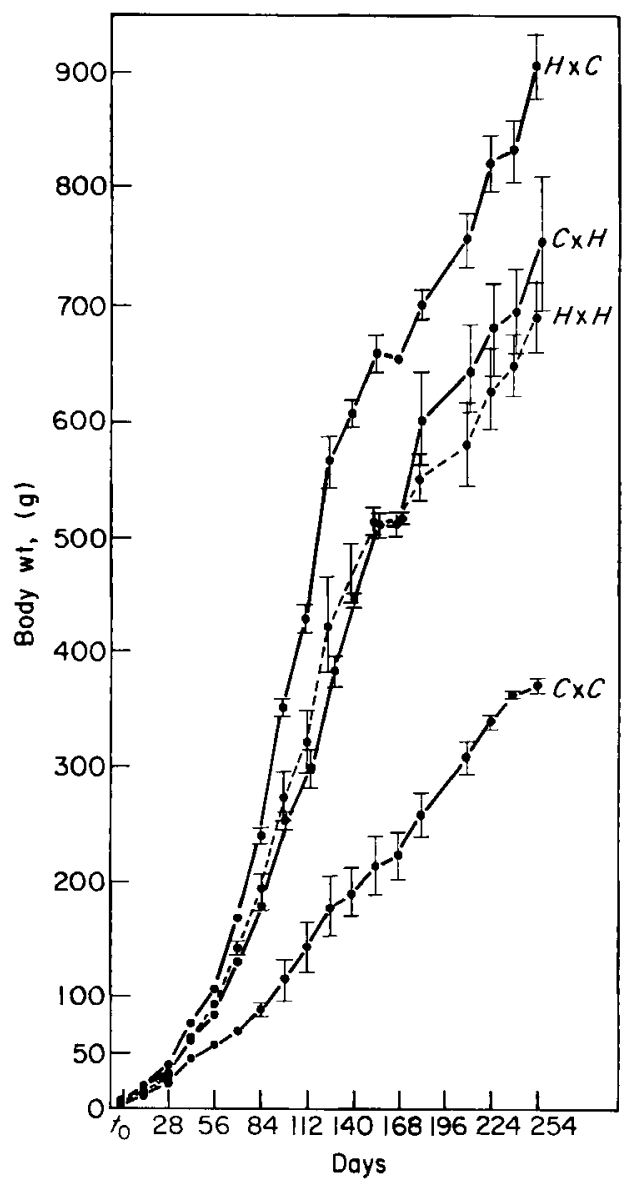

FIG. 4. Growth of $H$. longifilis $(H \times H), C$. gariepinus $(C \times C)$ and their reciprocal hybrids in the 1989 experiment. Vertical bars indicate range of replicates. 
TABLE IV. Sex-ratio (number of males/number of females) and mean body weight of females and males for $H$. longifilis $(H \times H), C$. gariepinus $(C \times C)$ and their reciprocal hybrids after 307 days of age in the 1989 experiment (means of duplicates)

\begin{tabular}{lcccc}
\hline \multirow{2}{*}{$\begin{array}{l}\text { Fish } \\
\text { group }\end{array}$} & $\begin{array}{c}\text { No. of } \\
\text { fish }\end{array}$ & $\begin{array}{c}\text { Sex } \\
\text { ratio }\end{array}$ & & \multicolumn{2}{c}{ Bodywt. (g) } \\
\hline$H \times H$ & 69 & 1.09 & $708 \pm 71$ & $681 \pm 59$ \\
$H \times C$ & 56 & $1 \cdot 15$ & $890 \pm 141$ & $923 \pm 152$ \\
$C \times C$ & 34 & 1.27 & $261 \pm 98$ & $454 \pm 92$ \\
$C \times H$ & 44 & 1.00 & $761 \pm 191$ & $738 \pm 173$ \\
\hline
\end{tabular}

$(P<0.05)$ and also indicated the low discriminating power of the statistics when data are transformed to mean SGR. After comparison on a RWG basis, unequal growth rates were also found between the two hybrid groups $(P<0.05)$, while no significant difference was shown between $H$. longifilis and $H \times C$ hybrids (Table III).

During this investigation, the lowest survival rate was observed in C. gariepinus $(53 \%)$ and the highest in $H$. longifilis $(96 \%)$. In both hybrids, the survival rates were intermediate ( 80 and $61 \%$ for $H \times C$ and $C \times H$ respectively) but did not differ significantly from those found in their maternal parents. Most of the mortalities occurred during the first half of the grow-out period when the water salinity remained below $3 \mathrm{~g}^{-1}$.

Mean FCRs were similar for all groups and ranged between 3.91 and 4.07 (Table III). These high values can be explained by elevated feeding rations. In $H$. longifilis, an increase in FCR was already observed when feeding ration exceeded $3 \%$ of fish biomass for fish around $500 \mathrm{~g}$ mean weight (Legendre, 1991). In the present study, FCR remained below 2 until the middle of the grow-out period (126 days).

\section{SEX-RATIO AND GROWTH COMPARISON BETWEEN SEXES}

At the end of the grow-out trial, all the fish were killed for gonadal sex identification. Sex ratio did not differ significantly from 1 to 1 (Table IV).

A comparison of mean weights showed a strong differential growth related to sex, in favour of males, for $C$. gariepinus $(P<0 \cdot 01)$. No significant difference was found between male and female growth rates either for $\boldsymbol{H}$. longifilis or both hybrids (Table IV).

\section{WEIGHT AND AGE AT FIRST SEXUAL MATURITY}

The temporal evolution of mean GSI and proportion of maturing females is given in Fig. 5 for $H$. longifilis and $H \times C$ hybrids spawned in March 1987. In $H$. longifilis, the first females $(20 \%)$ with ovaries containing oocytes at an advanced stage of vitellogenesis were observed in late March 1988. Two months later, at the beginning of the major rainy season (June), the proportion of maturing females exceeded $80 \%$. In $H \times C$ hybrids, the first maturing females were observed approximately one month later than in $H$. longifilis. But, the proportion of 
TABLE V. Range of weight and age at which $50 \%$ females reached first sexual maturity in the three hybridization experiments carried out in 1987, 1988 and 1989

\begin{tabular}{|c|c|c|c|c|c|c|c|c|}
\hline \multirow{2}{*}{$\begin{array}{l}\text { Fish } \\
\text { group }\end{array}$} & \multicolumn{2}{|c|}{$1987^{*}$} & \multicolumn{3}{|c|}{$1988 \dagger$} & \multicolumn{3}{|c|}{$1989 \dagger$} \\
\hline & $\begin{array}{l}\text { Body wt. } \\
\text { (g) }\end{array}$ & $\begin{array}{c}\text { Age } \\
\text { (months) }\end{array}$ & $\begin{array}{l}\text { Body wt. } \\
\text { (g) }\end{array}$ & $\begin{array}{c}\text { Age } \\
\text { (months) }\end{array}$ & $\begin{array}{c}\text { Final } \% \text { of } \\
\text { maturing } \\
\text { females }\end{array}$ & $\begin{array}{c}\text { Body wt. } \\
\text { (g) }\end{array}$ & $\begin{array}{c}\text { Age } \\
\text { (months) }\end{array}$ & $\begin{array}{l}\text { Final } \% \text { of } \\
\text { maturing } \\
\text { females }\end{array}$ \\
\hline$H \times H$ & $200-300$ & $13-14$ & $600-700$ & $12-13$ & 80 & $>700$ & $>10$ & 30 \\
\hline$H \times C$ & $800-1000$ & $20-21$ & $>1000$ & $>15$ & 23 & $>850$ & $>10$ & 0 \\
\hline$C \times C$ & - & - & $150-200$ & $6-7$ & 100 & $100-150$ & $5-6$ & 100 \\
\hline$C \times H$ & 一 & - & $>950$ & $>15$ & 24 & $>750$ & $>10$ & 0 \\
\hline
\end{tabular}

\footnotetext{
*For the 1987 experiment, the temporal evolution of the percentage of maturing females is given in Fig. 5.

fIn the 1988 and 1989 experiments, the fish were killed at 15 and 10 months of age respectively. The percentages of maturing females registered at the end of those experiments are indicated.
}

maturing females remained below $20 \%$ for several months and exceeded $50 \%$ only during the minor rainy season (October-November 1988), when fish were 20-21 months old. The observations of the three experiments are consistent (Table V). They confirm that sexual maturity occurs later in both hybrids than in $H$. longifilis. They also show that first sexual maturity of females is attained much earlier in C. gariepinus (5-7 months) than in $H$. longifilis (12-14 months of age). Within a given group, the age at first maturity remained approximately the same for the three experiments. But, because of discrepancies in growth rates due to a gradual optimization of rearing conditions, the weights at first maturity varied from one experiment to another. In all situations (fish group or experiment), an increase in the proportion of maturing females was always observed just before or during a rainy season (May-July or October-November), which corresponds with the reproductive period of these species in nature.

Except for C. gariepinus for which no precise data are available, sexual maturity appeared earlier in males than in females. In the 1987 experiment, first sexual maturity occurred after 7-9 months of age in both $H$. longifilis or $H \times C$ hybrid males and, after 10-11 months, all the males had developed testes containing intratesticular sperm. Similarly, in the 1989 experiment where the fishes were killed after 10 months of age, more than $80 \%$ of $H$. longifilis and of both hybrid males were found to be mature while at that time the proportion of maturing females was still between 0 and $30 \%$ in these groups (Table V).

\section{GONAD DEVELOPMENT AND GAMETE PRODUCTION}

Except for difference in age and weight at first maturity, the general pattern of gonadal development (GSI, size and colour of eggs, fecundity) appeared to be similar in H. longifilis and C. gariepinus. However, several abnormalities in gonadal development of hybrids were observed regularly in the different experiments performed.

In females, the mean GSI of hybrids always remained very low in comparison to that found in the parental species (Figs 5 and 6). For fish spawned in 1987 and killed 28 months later, in July 1989 , the mean GSI of mature females was $16.4 \%$ in 


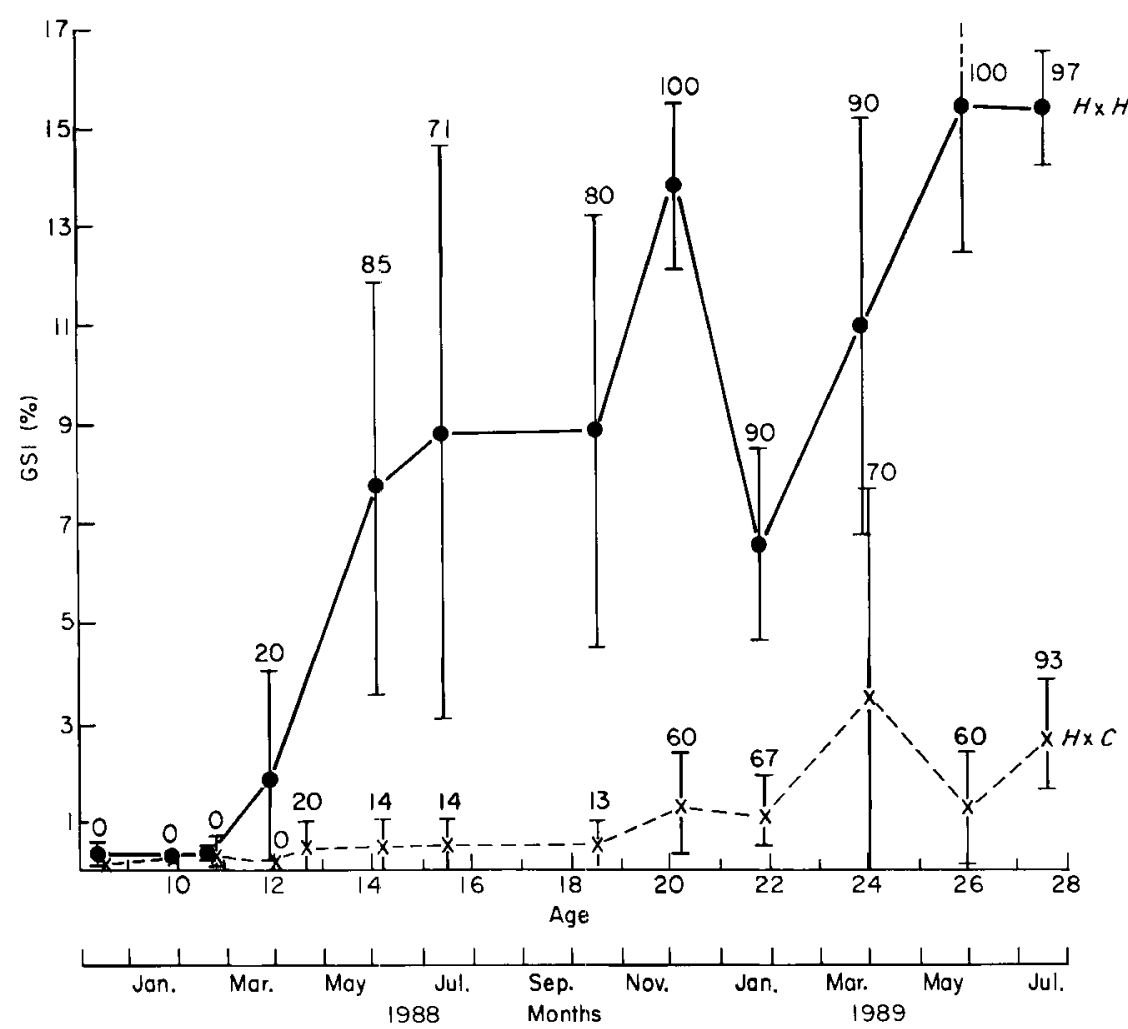

FIG. 5. Evolution of average GSI in relation to season and age in females of $H$. longifilis $(H \times H)$ and $H \times C$ hybrid $(H \times C)$ born in March 1987. Vertical bars refer to the confidence interval of the mean GSI with $5 \%$ probability. Figures in graph refer to percentages of maturing females.

H. longifilis compared to $3.2 \%$ in $H \times C$ hybrids. For fish spawned in 1988 and killed 15 months later (also in July 1989), the mean GSIs were 7.7, 21.6 and 1.3\% for $H$. longifilis, $C$. gariepinus and $H \times C$ hybrid respectively. At that time, only a single mature female $C \times H$ hybrid was found, and it also displayed a very low GSI $(0.7 \%)$. In the 1989 experiment, at 10 months of age, females with fully ripe ovaries were found only in C. gariepinus.

Although poorly developed in size, the actual mature stage of the hybrid ovaries was confirmed by the presence of oocytes which had reached a post-vitellogenic stage. The mean diameter of these oocytes tended to be greater in the hybrids than in the parental species (Fig. 6). The lower values of hybrid GSI correspond with a drastic reduction in mean relative fecundity. At the same age and similar weight, egg production of hybrids reached approximately $15 \%$ of that of $H$. longifilis. Mean fecundities were 9000 and 20000 eggs per kg body weight in $H \times C$ hybrids, while in $H$. longifilis the corresponding fecundities were 74000 and 120000 eggs per $\mathrm{kg}$ for populations of 15 and 28 months of age respectively. Several specimens with ovarian tumours were observed in both reciprocal hybrids. These tumours were generally rounded, whitish and rather hard. They were never observed in hybrid males nor in parental species of either sex. The development of these tumours within the ovaries was highly variable depending on individuals. All intermediates 

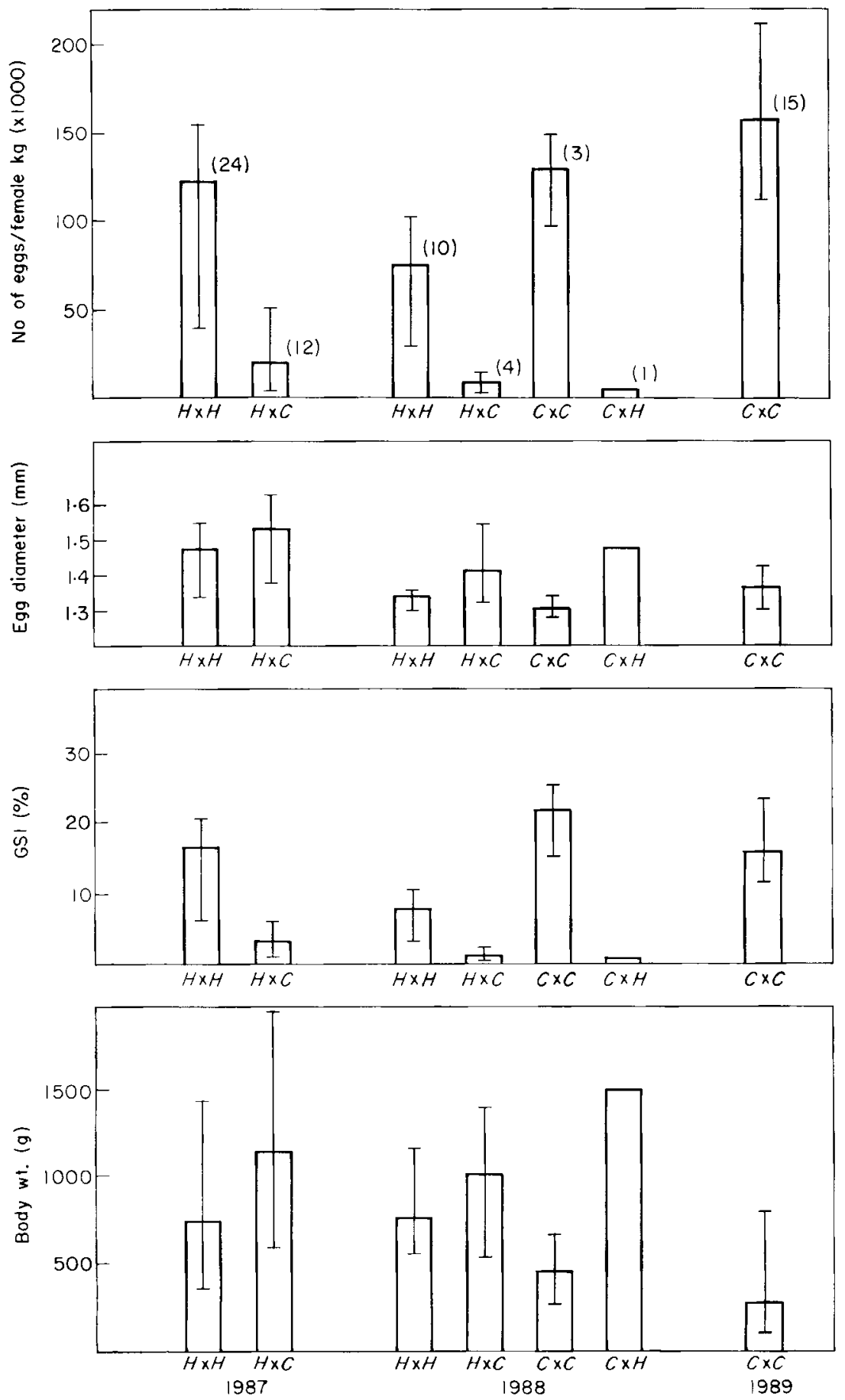

FIG. 6. Mean body weight, GSI, egg diameter and relative fecundity for mature females of $H$. longifilis $(H \times H), C$. gariepinus $(C \times C)$ and their reciprocal hybrids. Age of observed females was 28,15 and 10 months in the 1987, 1988 and 1989 experiments respectively. Vertical bars indicate differences between extreme values. Figures in parentheses indicate number of fish observed. 

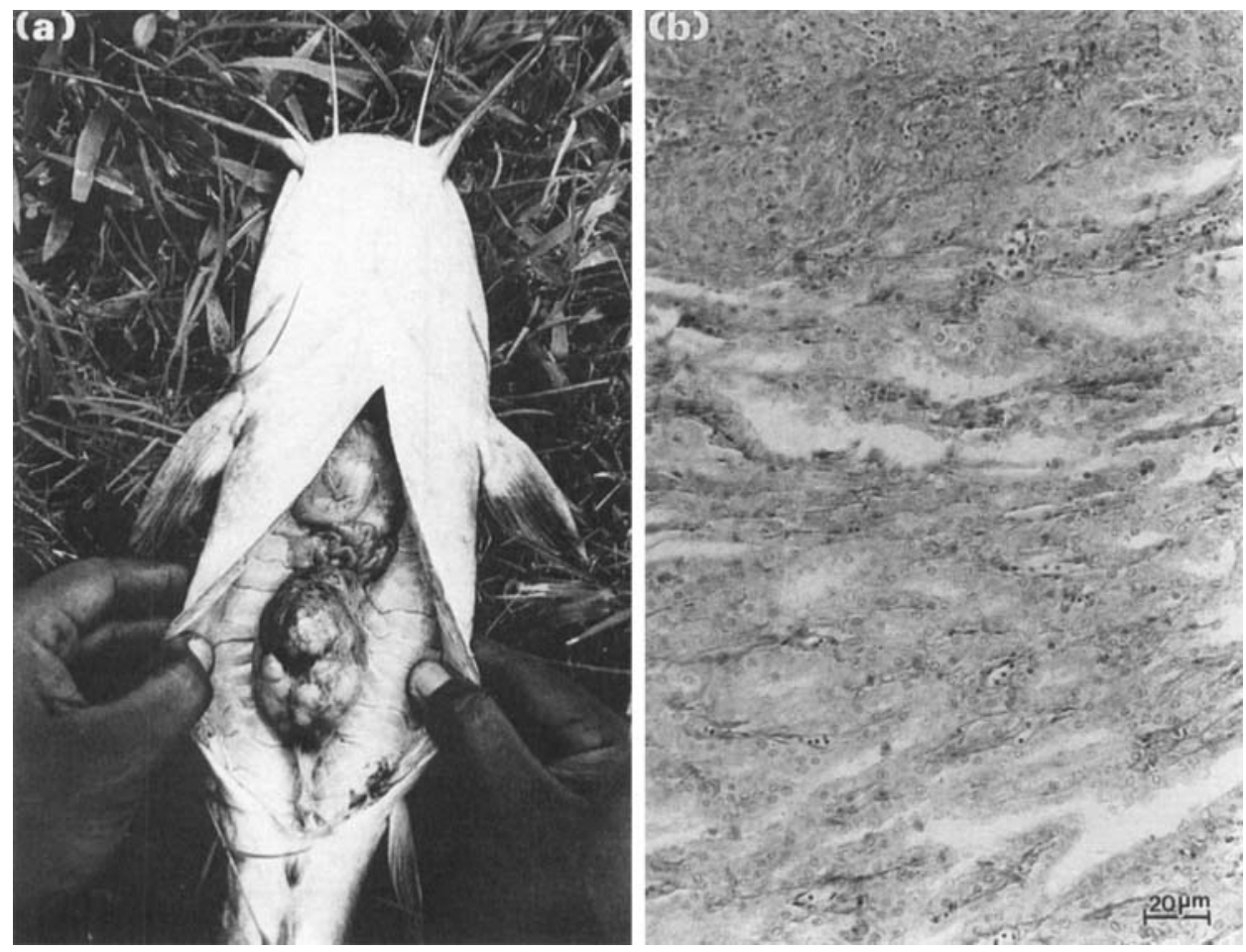

FIG. 7. (a) General appearance of a tumoral ovary from a sterile hybrid female. (b) Histological appearance of a tumour within the ovary of a sterile hybrid female. No germ cell can be observed.

were found, from a complete absence to a total invasion of the ovarian cavity. In the latter case, the fish were completely sterile [Fig. 7(a)]. Tumours were detected in nearly $20 \%$ of the hybrid females $(n=196)$, resulting from hyper-development of somatic conjunctive tissue (Figs 7 and 8).

In males, the morphological aspect of the testes also differed noticeably between hybrids and parental species. Testes of mature hybrid males were turgescent and of a translucent orange colour, while in both $H$. longifilis and $C$. gariepinus they were more flat and of whitish-brown opaque colour. Mean GSI and mean spermatozoa concentration per unit of semen volume are presented in Table VI. As no striking difference appeared between males of the same group examined during the course of the experiments, the data were pooled. Contrary to the situation in females, GSI of mature males tended to be greater in hybrids $(0.93 \pm 0.40$ and $0.54 \pm 0.13$ in $H \times C$ and $C \times H$ respectively) than in parental species $(0.37 \pm 0.19$ and $0.49 \pm 0.19$ in $H$. longifilis and $C$. gariepinus respectively). This was particularly true for fish in their second year of life (1987 experiment), during which GSIs of hybrid males were generally between 1 and $2 \%$ while the maximum value in $H$. longifilis was only $0.9 \%$. Intratesticular semen production was generally more abundant in hybrids. However, the semen was extremely dilute (translucent) with a mean spermatozoa concentration ( 1.5 to $9.8 \times 10^{7}$ spermatozoa ml ${ }^{-1}$ semen) two orders of magnitude lower than in parental species ( 2.9 to $4.0 \times 10^{9}$ spermatozoa $\mathrm{ml}^{-1}$ semen).

Histological examination of the gonads confirmed the macroscopic observations. 

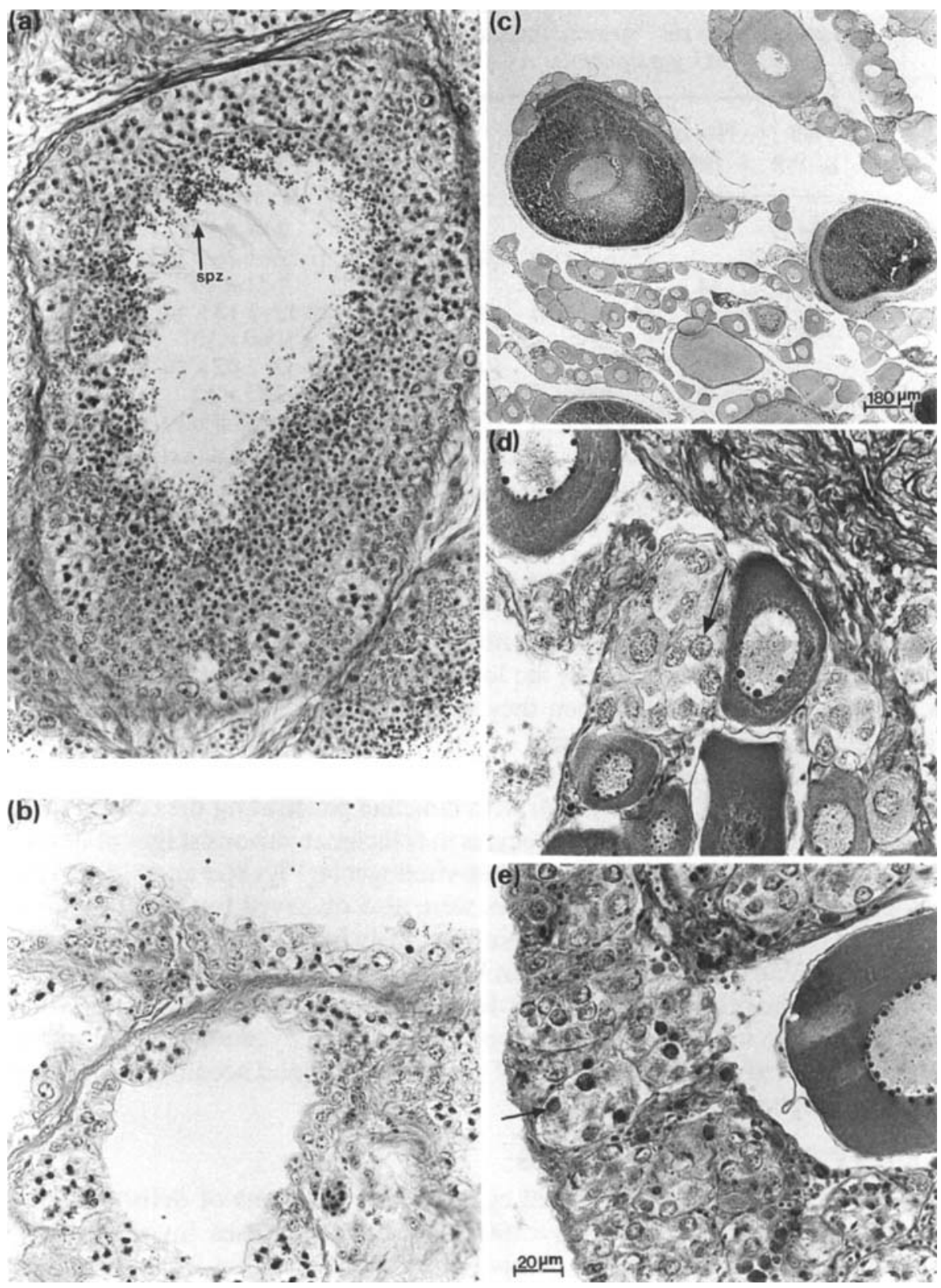

Fig. 8. (a) Transverse section through a typical testicular lobule in the testis of a normal male from a parental species, showing male germinal cells cysts at various stage of development, and spermatozoa (spz) in the central lumen. Scale as Fig. 8(e). (b) Transverse section through a testicular lobule in the testis of a hybrid male, showing female and smaller cysts. Spermatozoa are rare (not visible in this section). Scale as Fig. 8(e). (c) Transverse section through a typical ovary of a normal female from a parental species. Oocytes at all stages of development can be observed within the ovarian lamellae. (d) Detailed view through an ovarian lamella in the ovary of a normal female from a parental species, showing young oocytes at early steps of the meiotic prophase (arrow). Scale as Fig. 8(e). (e) Detailed view through an ovarian lamella in the ovary of a hybrid female, showing pycnotic nuclei (arrow) among early female germ cells nests, instead of normal figures of early meiotic prophase. 
TABLE VI. Mean body weight, gonadosomaticindex and number of spermatozoa $\mathrm{ml}^{-1}$ semen in mature males of $H$. longifilis $(H \times H)$, C. gariepinus $(C \times C)$ and reciprocal hybrids

\begin{tabular}{|c|c|c|c|c|}
\hline $\begin{array}{l}\text { Fish } \\
\text { group }\end{array}$ & $\begin{array}{l}\text { No. of } \\
\text { fish }\end{array}$ & $\begin{array}{l}\text { Body wt. } \\
\text { (g) }\end{array}$ & $\begin{array}{l}\text { GSI } \\
(\%)\end{array}$ & $\begin{array}{l}\text { No. of spermatozoa } \\
\mathrm{ml}^{-1} \text { semen }\end{array}$ \\
\hline$H \times H$ & 9 & $\begin{array}{c}823 \\
(556-1278)\end{array}$ & $\begin{array}{c}0.37 \\
(0 \cdot 14-0.78)\end{array}$ & $\begin{array}{c}2.94 \times 10^{9} \\
\left(1.26-4.26 \times 10^{9}\right)\end{array}$ \\
\hline$H \times C$ & 14 & $\begin{array}{c}1160 \\
(438-2190)\end{array}$ & $\begin{array}{c}0.93 \\
(0 \cdot 17-2 \cdot 31)\end{array}$ & $\begin{array}{c}1.51 \times 10^{7} \\
\left(0.13-3.13 \times 10^{7}\right)\end{array}$ \\
\hline$C \times C$ & 7 & $\begin{array}{c}394 \\
(305-578)\end{array}$ & $\begin{array}{c}0.49 \\
(0.24-0.76)\end{array}$ & $\begin{array}{c}4.00 \times 10^{9} \\
\left(2.32-7.02 \times 10^{9}\right)\end{array}$ \\
\hline$C \times H$ & 9 & $\begin{array}{c}856 \\
(513-1325)\end{array}$ & $\begin{array}{c}0.54 \\
(0.31-0.79)\end{array}$ & $\begin{array}{c}9.81 \times 10^{7} \\
\left(0.98-18.8 \times 10^{7}\right)\end{array}$ \\
\hline
\end{tabular}

Extreme values are given in parentheses.

The testes of both parental species are of the lobular type, as defined by Billard et al. (1982). In mature individuals, the lobules are generally open, edged by cysts at all stages of development and with numerous free spermatozoa in their central lumen [Fig. 8(a)]. In the hybrids, the lobules were largely open, but contained a low number of spermatozoa when they were not empty [Fig. 8(b)]. Cysts at the spermatid stage were also quite rare.

In both $H$. longifilis and $C$. gariepinus, the developed ovary is a hollow, sac-like structure consisting of an outer wall with lamellae penetrating the central lumen. The lamellae contain oogonia and oocytes in follicles at various stages of development, vitellogenic (stage I and II) and post-vitellogenic [Figs 8(c) and 8(d)]. Atretic vitellogenic or post-vitellogenic follicles were also observed but generally in low proportion. Similar atretic follicles have previously been described in C. gariepinus by Richter \& Van den Hurk (1982). In hybrids, the main differences consisted in an increase of the proportion of artetic follicles (mainly at the first stage of vitellogenesis), and also in large numbers of oogonia showing pycnotic nuclei [Fig. 8(e)]. Both processes led to a low efficiency of gametogenesis and accounted for the low fecundity of hybrids.

\section{VIABILITY OF HYBRID GAMETES}

The mean percentages of hatched eggs and the fractions of deformed larvae (=deformed larvae/hatched eggs $\times 100$ ) obtained in crosses involving hybrid gametes (F2 and backcross) are compared to those resulting from intraspecific fertilization (Table VII). In order to keep comparable conditions, the volume of hybrid semen used was 100 times greater than that of parents. This compensated for the low spermatozoa production of hybrids and resulted in similar numbers of spermatozoa per ovum during fertilization $(>50000)$. Nevertheless, hybrid sperm always led to lower hatching rate and higher proportion of deformed larvae than semen from pure species. But, normal larvae were obtained in all cases. The quantity of eggs collected after hormonal treatment from the hybrid females was extremely low (mean of 12000 eggs per kg B.w.) compared to 70000 and 106000 eggs per kg B.w.) for H. longifilis and C. gariepinus respectively. In spite of variable 
TABLE VII. Mean hatching rates obtained in backcrosses and F2 cross in comparison with H. longifilis and C. gariepinus controls

\begin{tabular}{|c|c|c|c|c|c|}
\hline & \multirow{2}{*}{$\begin{array}{l}\text { H. longifilis } \\
\text { (female) }\end{array}$} & \multirow{2}{*}{$\begin{array}{l}\text { C. gariepinus } \\
\text { (female) }\end{array}$} & \multicolumn{3}{|c|}{$H \times C$ hybrid } \\
\hline & & & 1 & 2 & 3 \\
\hline $\begin{array}{l}\text { H. longifilis } \\
\text { (male) }\end{array}$ & $\begin{array}{c}83.9 \\
(16.0)\end{array}$ & - & $\begin{array}{c}80 \cdot 3 \\
(90 \cdot 7)\end{array}$ & $\begin{array}{c}42 \cdot 8 \\
(22 \cdot 2)\end{array}$ & $\begin{array}{c}48 \cdot 5 \\
(25 \cdot 4)\end{array}$ \\
\hline $\begin{array}{l}\text { C. gariepinus } \\
\text { (male) }\end{array}$ & - & $\begin{array}{c}52 \cdot 3 \\
(59.9)\end{array}$ & $\begin{array}{c}72 \cdot 7 \\
(90 \cdot 7)\end{array}$ & - & - \\
\hline$H \times C$ hybrid & $\begin{array}{c}46.9 \\
(59 \cdot 5)\end{array}$ & $\begin{array}{c}11 \cdot 5 \\
(89 \cdot 6)\end{array}$ & $\begin{array}{c}44 \cdot 7 \\
(83 \cdot 5)\end{array}$ & - & - \\
\hline
\end{tabular}

Fraction of deformed larvae (deformed larvae/hatched eggs $\times 100$ ) are given in parentheses.

egg quality (Table VII), hybrid eggs could lead to normal larvae after hatching. In each situation ( $\mathrm{F} 2$ or backcrosses), these larvae developed into normal fry which appeared to be viable until they were killed after 53 days.

\section{DISCUSSION}

The feasibility of reciprocal cross-breeding between $C$. gariepinus and $H$. longifilis was demonstrated in the present study. Hatching rates and proportions of deformed larvae obtained after hybridization were always very close to those obtained in intraspecific controls. Hubbs (1970) and Hester (1970) suggested the use of hybridization to demonstrate phylogenetic relationships in fish. Our results suggest that the two species are closely related, although presently belonging to different genera. Comparative studies on morphological characters, enzymatic polymorphism or karyology also tend to support this hypothesis (Teugels et al., $1990,1992 a, b)$. However, a proper phylogenetic classification needs additional out-group comparisons with other clariids and other catfish families.

The most important morphological difference between $C$. gariepinus and $H$. longifilis is the presence in the latter species of a large adipose fin originating immediately behind the rayed dorsal fin and reaching the caudal fin base. The hybrid specimens always displayed an intermediate external morphology, with an adipose fin of about half the size of that found in $H$. longifilis. This intermediate morphology suggests that the products of the present hybridization were 'true' hybrids resulting from the fusion of the genetic material of both parents, and not parthenogenetic as observed on several occasions in fish (Chevassus, 1983). This was also demonstrated by the description of hybrid karyotypes (Teugels et al., $1992 a$ ) and in a study on their enzymatic variation (Teugels et al., 1992b).

The hybrids were normally viable and their survival was strongly influenced by their maternal parent. The low survival rate of $C$. gariepinus and $C \times H$ hybrid during larval rearing may be related to a poor quality of the Clarias eggs, but mortality of older fish was probably caused by other factors. During the grow-out trial, survival of C. gariepinus $(53 \%$ ) was also much lower than that of $H$. longifilis $(96 \%)$. This could indicate a mediocre adaptability of $C$. gariepinus to the lagoon 
water. However, most of the mortality occured during the first half of the trial when the salinity was still below $3 \mathrm{~g}^{-1}$. Moreover, Chervinsky (1984) and Clay (1977) reported that fingerlings and adults of C.gariepinus can tolerate salinities up to 10 and $15 \mathrm{~g} \mathrm{l}^{-1}$ respectively. Thus, except for the 1987 experiment in which early and total mortality of larvae occured at $8 \mathrm{~g} \mathrm{l}^{-1}$, salinity was probably not the main mortality factor of $C$. gariepinus. A similar situation was observed for Oreochromis niloticus, for which heavy mortality rates were experienced regularly during rearing trials in the Ebrie lagoon, even in the oligohaline zones (Doudet, 1991).

Because of the size segregation performed at the initiation of the grow-out trial (day 53), the growth rates obtained in the 1989 experiment may not be conclusive for the whole of the populations under investigation. However, these growth rates can be considered as representative for populations under usual culture conditions since size segregation of fingerlings is a common and necessary procedure in clariid culture, recommended for both $C$. gariepinus and $H$. longifilis in order to avoid cannibalism (Viveen et al., 1985; Legendre, 1991). The growth rates obtained for C. gariepinus figure well in the range of those reported in literature. In the present study, the fish reached a mean weight of 200 and $390 \mathrm{~g}$ in 200 and 307 days respectively. Viveen et al. (1985) reported that $C$. gariepinus reached $200 \mathrm{~g}$ after 180 days from $1 \mathrm{~g}$ fingerlings when reared in pond monoculture $\left(10\right.$ fish per $\left.\mathrm{m}^{2}\right)$ and fed with a $35 \%$ pelleted feed. Egwui (1986) obtained a growth from $96 \mathrm{~g}$ to $418 \mathrm{~g}$ mean weight in 302 days with fish reared in a concrete pond, and fed with a mixture made of equal weights of fish feed pellets, groundnut cake and palm kernel cake. Under optimal conditions of intensive culture with trout pellets as feed, $C$. gariepinus reached approximately $200 \mathrm{~g}$ after 172 to 228 days of age and $400 \mathrm{~g}$ after 233 to 258 days of age depending on the feeding level (Henken et al., 1987). In $H$. longifilis, the growth rate obtained in the present experiment (694 $\mathrm{g}$ in 307 days) is also very close to those reported for different monoculture conditions at the Layo station (Legendre, 1991). These results are important because they indicate that, as far as growth rate is concerned, $H$. longifilis is more profitable than $C$.gariepinus for fish culture.

In the present study, sexual maturity of $C$. gariepinus was achieved after 5-7 months of age. Richter et al. (1982) also observed that at least $50 \%$ of the females of this species had ovaries containing predominantly post-vitellogenic oocytes after 6 months of age. In $H$. longifilis, sexual maturity of females occured later, after 12-14 months, confirming previous observations (Legendre, 1986). Although fish growth differed noticeably among experiments, age at first maturity showed little variation. This indicates that in $H$. longifilis age is more important than size in onset of first maturity. Sexual maturity of females occured later in hybrids than in parental species. In $H$. longifilis and both hybrid males, sexual maturity occured approximately at the same time and sooner than in females.

If the development of gonads is at the expense of somatic tissue, then the early maturity of $C$. gariepinus could be responsible, at least in part, for its lower growth rate. However, the growth difference between this species and $H$. longifilis was already noticeable in immature fish (Fig. 4, Table II).

The results have also shown that the growth of $H \times C$ hybrids is faster than that of $C \times H$ hybrid. The comparison between the growth rates of $H \times C$ hybrid and $H$. longifilis was more difficult to interpret. In the 1987 experiment, the growth rate of $H \times C$ hybrid was obviously faster than that of $H$. longifilis up to 57 days of age. 
However, this trial was performed in environmental conditions characterized by a high salinity $\left(8 \mathrm{~g} \mathrm{l}^{-1}\right)$. Survival was very low for both fish groups but remained higher in the hybrid than in $H$. longifilis. It is possible that these unfavourable conditions were tolerated better by the hybrid. In the 1989 experiment, initiated in fresh water, no differences in growth rate were observed between both groups up to 53 days of age. At the end of the grow-out trial, $H \times C$ hybrids reached the highest final weight but when the initial weight difference was taken into account through SGR or RWG, no difference in growth rate could be indicated between the two groups. Thus, it can be assumed that the growth rate of $H \times C$ hybrid is either equal to or greater than that of $H$. longifilis, and that the expression of an heterotic effect for growth could depend on environmental conditions of rearing.

In C. gariepinus, a sex-linked difference in growth rate, in favour of males, was reported previously (El Bolock, 1972; De Kimpe \& Micha, 1974; Henken et al., 1987). It was never observed in $\boldsymbol{H}$. longiflis, even for fully mature fish weighing between 2 and $7 \mathrm{~kg}$ (M. Legendre, unpublished). The hybrids never showed this sex-linked growth difference.

The $1: 1$ sex-ratio found in both parental species and their reciprocal hybrids supports the hypothesis of a similar mechanism of sex determination in the two species. Karyological analysis revealed the presence of differentiated sex chromosomes of the ZZ-ZW system in both $C$. gariepinus and $H$. longifilis. The identification of the hybrid sex on the basis of their gonads was also directly related to the presence of the ZZ or ZW chromosomes (Ozouf-Costaz et al., 1990; Teugels et al., 1992a).

Teugels et al. (1992a) found that the hybrids have a karyotype $(2 n=54)$ representing the sum of the haploid numbers of $H$. longifilis $(2 n=52)$ and $C$. gariepinus $(2 n=56)$. These unequal parental haploid numbers may have induced difficulties in chromosome pairing during meiosis, accounting for the low efficency of gametogenesis observed in the hybrids. However, small numbers of viable fry were obtained from $F 2$ or backcross fertilizations. This proved that, in spite of various abnormalities in their gonad development and a low quality of their gametes, male or female hybrids were not sterile. Thus, the risk of genetic contamination of natural fish stocks by hybrids escaping from fish culture facilities cannot be disregarded.

The authors are grateful to Jacques Slembrouck and Kouakou Kouassi (CRO, Abidjan) for their technical assistance.

\section{References}

Billard, R., Fostier, A., Weil, C. \& Breton, B. (1982). The endocrine control of spermatogenesis in teleost fish. Canadian Journal of Fisheries and Aquatic Sciences 39, 65-79.

Boonbrahm, M., Tarnchalanukit, W. \& Suraniranat, P. (1977). Experiments on hybridization of fresh-water catfish, Clarias macrocephalus Günther and Clarias batrachus. Research Report of the Kasetsart University, 143.

Clay, D. (1977). Preliminary observations on salinity tolerance of Clarias lazera from Israel. Bamidgeh 29, 102-109.

Chervinski, J. (1984). Salinity tolerance of young catfish, Clarias lazera (Burchell). Journal of Fish Biology 25, 147-149.

Chevassus, B. (1979). Hybridization in salmonids: results and perspectives. Aquaculture $17,113-128$. 
Chevassus, B. (1983). Hybridization in fish. Aquaculture 33, 245-262.

De Kimpe, P. \& Micha, J. C. (1974). First guidelines for the culture of Clarias lazera in Central Africa. Aquaculture 4, 227-248.

Doudet, T. (1991). Comparaison de la tolérance au milieu lagunaire saumâtre de différentes espèces et hybrides d'Oreochromis pour leur utilisation en aquaculture (lagune Ebrié, Côte d'Ivoire). In Proceedings of the International Workshop on Aquaculture Research in Africa. International Development Research Center (IDRC), Ottawa, Canada, in press.

Eding, E. H., Janssen, J. A. L., Kleine Staarman, G. H. J. \& Richter, C. J. J. (1982). Effects of human chorionic gonadotropin (HCG) on maturation and ovulation of oocytes in the catfish Clarias lazera (C.\& V.). In Proceedings of the International Symposium on Reproductive Physiology of Fish (Richter, C. J. J. \& Goos, H. J. Th., eds), p. 195. Wageningen: PUDOC.

Egwui, P. C. (1986). Yields of the African catfish, Clarias gariepinus (Burchell), from a low input, homestead, concrete pond. Aquaculture 55, 87-91.

El Bolock, A. R. (1972). The use of vertebrae for determining age and growth of the Nile catfish Clarias lazera (Cuv. \& Val.) in the A.R.E. Bulletin of the Institute of Oceanography and Fisheries, Cairo 2, 53-82.

Gabe, M. (1968). Techniques Histologiques. Paris: Masson.

Hecht, T. \& Lublinkhof, W. (1985). Clarias gariepinus $\times$ Heterobranchus longifilis (Clariidae: Pisces): a new hybrid for aquaculture? South African Journal of Science 81, 620-621.

Henken, A., Boon, J., Cattel, B. \& Lobee, H. (1987). Differences in growth rate and feed utilization between male and female African catfish, Clarias gariepinus (Burchell 1822). Aquaculture 63, 221-232.

Hester, E. (1970). Phylogenetic relationships of sunfishes as demonstrated by hybridization. Transactions of the American Fisheries Society 1, 100-104.

Hogendoorn, H. \& Vismans, M. M. (1980). Controlled propagation of the African catfish, Clarias lazera (C. \& V.). II. Artificial reproduction. Aquaculture 21, 39-53.

Hubbs, C. (1970). Teleost hybridization studies. Proceedings of the California Academy of Sciences 38, 289-298.

Legendre, M. (1983). Examen préliminaire des potentialités d'un silure africain Heterobranchus longifilis (Valenciennes, 1840) pour l'aquaculture en milieu lagunaire. Documents Scientifiques du Centre de Recherches Océanographiques, Abidjan 14, 97-107.

Legendre, M. (1986). Seasonal changes in sexual maturity and fecundity, and HCGinduced breeding of the catfish, Heterobranchus longifilis Val. (Clariidae), reared in Ebrié lagoon (Ivory Coast). Aquaculture 55, 201-213.

Legendre, M. (1991). Bilan des premiers essais d'élevage d'un silure africain, Heterobranchus longifilis (Clariidae), en milieu lagunaire (lagune Ebrié, Côte d'Ivoire). In Proceedings of the International Workshop on Aquaculture Research in Africa. International Development Research Center (IDRC), Ottawa, Canada, in press.

Moav, R. (1976). Genetic improvement in the aquaculture industry. FAO Technical Conference on Aquaculture, 26 May-2 June 1976, Kyoto, Japan, FIR:AQ/Conf/76:R.9.

Mukhopadathy, S. M. \& Dehadrai, P. V. (1987). Survival of hybrids between air-breathing catfishes Heteropneustes fossilis (Bloch) and Clarias batrachus (Linn.). Matsya 12-13, 162-164.

Ozouf-Costaz, C., Teugels, G. G. \& Legendre, M. (1990). Karyological analysis of three strains of the African catfish, Clarias gariepinus (Clariidae), used in aquaculture. Aquaculture 87, 271-277.

Richter, C. J. J. \& Van Den Hurk, R. (1982). Effects of 11-desoxycorticosterone-acetate and carp pituitary suspension on follicle maturation in the ovaries of the African catfish, Clarias lazera (C. \& V.). Aquaculture 29, 53-66.

Richter, C. J. J., Eding, E. H., Leuven, S. E. W. \& Van Der Wijst, J. G. M. (1982). Effects of feeding levels and temperature on the development of the gonad in the African catfish Clarias lazera (C. \& V.). In Proceedings of the International Symposium on 
Reproductive Physiology of Fish (Richter, C. J. J. \& Goos, H. J. Th, eds), pp. 147-150. Wageningen: PUDOC.

Sneed, K. E. (1971). Some current North American work in hybridization and selection of cultured fish. Report FAO/UNDP (TA) 2926, 143-150.

Tarnchalanukit, W. (1986). Experimental hybridization between catfishes of the family Clariidae and Pangasiidae in Thailand. Environmental Biology of Fishes 16, 317-320.

Teugels, G. G. (1982). Preliminary results of a morphological study of the African species of the subgenus Clarias (Clarias) (Pisces, Clariidae). Journal of Natural History, London 16, 439-464.

Teugels, G. G. (1986a). Clariidae. In Check-list of the Freshwater Fishes of Africa, CLOFFA II (Daget, J., Gosse, J. P. \& Thys van den Audenaerde, D. F. E., eds), pp. 66-101. Brussels: ISNB, Tervuren; MRAC, Paris: ORSTOM.

Teugels, G. G. (1986b). A systematic revision of the African species of the genus Clarias (Pisces, Clariidae). Annales du Musée Royal de l'Afrique Centrale 247, 1-199.

Teugels, G. G., Denayer, B.\& Legendre, M. (1990). A systematic revision of the African catfish genus Heterobranchus Geoffroy-Saint-Hilaire, 1809 (Pisces, Clariidae). Zoological Journal of the Linnean Society 98, 237-257.

Teugels, G. G., Ozouf-Costaz, C., Legendre, M. \& Parrent, M. (1992a). A karyological analysis of the artificial hybridization between Clarias gariepinus (Burchell, 1822) and Heterobranchus longifilis Valenciennes, 1840 (Pisces, Clariidae). Journal of Fish Biology 40, 81-86.

Teugels, G. G., Guyomard, R. \& Legendre, M. (1992b). Enzymatic variation in African clariid catfishes. Journal of Fish Biology 40, 87-96.

Viveen, W. J. A. R., Richter, C. J. J., Van Oordt, P. G. W. J., Janssen, J. A. L. \& Huisman, E. A. (1985). Manuel pratique de pisciculture du poisson chat africain (Clarias gariepinus). Département de Pisciculture et des pêches de l'Université Agronomique de Wageningen, Belgium.

Wohlfarth, G. W. \& Hulata, G. I. (1981). Applied genetics of tilapias. ICLARM Studies and Reviews Vol. 6. Manila: ICLARM. 